\title{
Assessment of phase formation in lime-based mortars with added metakaolin, Portland cement and sepiolite, for grouting of historic masonry
}

\author{
Alberto Sepulcre-Aguilar ${ }^{\text {a,* }}$, Francisco Hernández-Olivares ${ }^{\text {b }}$ \\ a Departamento de Ciencias y Técnicas Aplicadas, Escuela Superior de Conservación y Restauración de Bienes Culturales de Madrid, C/ Guillermo Rolland, 2, 28013 Madrid, Spain

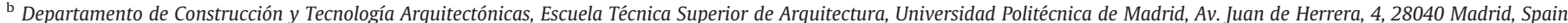

\section{A R T I C L E I N F O}

Article history:

Received 22 January 2008

Accepted 27 August 2009

\section{Keywords:}

Blended lime-cement mortars (D)

Restoration mortars (E)

Pozzolanic additions (D)

Metakaolin (D)

Thermal analysis (B)

\begin{abstract}
A B S T R A C T
Lime-based mortars containing pozzolanic additions of metakaolin, sepiolite and white Portland cement are studied in order to determine their performance as historic masonry conservation mortars. Hydration products on metakaolin-lime blended mortars include stable and metastable phases. The presence of such products has been studied by means of DTA and XRD analysis, concluding that the selection between them is mainly related with the water-lime ratio. Sepiolite addition to metakaolin-lime mortars has shown to inhibit $\mathrm{C}_{4} \mathrm{AH}_{13}$ formation. Therefore, the influence of phase distribution on the mechanical resistance is considered. Finally, compounds production on blended lime-white Portland cement was compared to natural hydraulic lime ones, and as a result, no remarkable differences appeared, apart from traces of possible cement Portland addition to the latter, usually not mentioned in the nominal composition supplied by the manufacturers of lime binders.
\end{abstract}

(c) 2009 Elsevier Ltd. All rights reserved.

\section{Introduction}

Historic masonry conservation is mainly based on two different strengthening techniques: repointing and grouting [1]. Likely considerations, recommend the use of lime-based mortars for both preservation techniques, mainly because according to Mack and Speweik these mortars "must be softer or more permeable than the masonry units and no harder or more impermeable than the historic mortar to prevent damage to the masonry units" [2].

Although traditional lime-based mortars can be useful for repointing because of their aerial setting mechanism; some hydraulic behaviour is needed for grouting mortars, because of their occlusion and the necessity of having a better mechanical performance. For this reason this paper presents a research on modified lime-based hydraulic grouts for injection into pores and cavities to regain structural soundness of masonry, in historic buildings.

Since the 1980s, the use of Portland cement-based mortars for this restoration purpose has been criticized because of its production of salts, high stiffness and strength, setting shrinkage and cracking [3-5]. At the same time, the adhesion to the old historic supports of Portland cement-based mortars is generally poor, their thermal conductivity is usually higher, and they have open porosity lower than the limebased ones. Because of this, and as a result of the better compatibility proved with the historic masonry supports, lime-based mortars are proposed as the best restoration mortar choice.

\footnotetext{
* Corresponding author. Tel.: +34 915482737; fax: +34915426390

E-mail addresses: asepulcrea@arquired.es (A. Sepulcre-Aguilar) f.hernandez@upm.es (F. Hernández-Olivares).
}

Nevertheless, much of the restoration and conservation works on historic masonry buildings have to be made by grouting. This means that mortars to be applied for this general purpose must harden in conditions of no air contact and usually high humidity; however, some setting speed is needed, mainly in order to assume the safety of the whole preservation work. Also, to avoid the risk of any migration of the binder to the surface where stuccos, paintings, or other artistic works could be located, the mentioned hydraulic behaviour is essential for these grouting mortars.

One solution is to use lime-based mortars with additions of pozzolans or other similar hydraulic activator materials. Crushed bricks and tiles have been used in ancient times as artificial pozzolans together with lime. In this case, metakaolin (MK) seems to be the main active element [6]. Many studies have been done about the effects of MK additions to cement mortars in order to achieve strength and durability [7], but there are not so many investigations on MKlime mortars and their influence on historic masonry requirements. On the other hand, lime-Portland cement blended mortars have frequently been used during the last two centuries for different situations. As a result of the increasing rejection to the use of Portland cement in restoration works, little research has been accomplished about these blended mortars in comparison to other hydraulic lime ones. Furthermore, sepiolite additions have been proposed as carriers of biocides in lime restoration mortars [8,9], but no research has been found about its effects on the components of other hydraulic lime mortars and its possible long term behaviour.

Some recent studies describe the relation of hydration products on chloride ion binding capacity in lime-MK mixtures [10] or the effect of high temperature on the formation and evolution of hydraulic 
Table 1

Chemical composition of the addition products used for this research.

\begin{tabular}{lrrlllllll}
\hline $\begin{array}{l}\text { Oxides } \\
(\%)\end{array}$ & $\mathrm{SiO}_{2}$ & $\mathrm{Al}_{2} \mathrm{O}_{3}$ & $\mathrm{MgO}$ & $\mathrm{CaO}$ & $\mathrm{Fe}_{2} \mathrm{O}_{3}$ & $\mathrm{Na}_{2} \mathrm{O}$ & $\mathrm{K}_{2} \mathrm{O}$ & $\mathrm{TiO}_{2}$ & $\begin{array}{l}\text { L.O.I. } \\
1000\end{array}$ \\
\hline Kaolin & 48.00 & 37.50 & - & 0.10 & 0.53 & - & 0.50 & 0.14 & 13.30 \\
Sepiolite & 60.50 & 2.40 & 23.8 & 0.50 & 0.90 & 0.10 & 0.50 & - & 11.30 \\
\hline
\end{tabular}

Table 2

Specifications of samples used in this research.

\begin{tabular}{|c|c|c|c|c|c|}
\hline \multirow[t]{2}{*}{ Series } & \multicolumn{2}{|l|}{ Bulk composition } & \multirow[t]{2}{*}{$\mathrm{W} / \mathrm{B}$} & \multicolumn{2}{|c|}{ Curing conditions } \\
\hline & & Addition & & Duration & $\begin{array}{l}\text { Water/temp. Air } \\
\left({ }^{\circ} \mathrm{C}\right)\end{array}$ \\
\hline MK & Lime-metakaolin-sand & & & & \\
\hline MK-A & $1: 1: 3^{\mathrm{a}}$ & & 1.5 & 21 days & 60 \\
\hline MK-B & $2: 1: 7$ & & 1.5 & 35 days & 60 \\
\hline MK-C & $1: 1: 3$ & & 1.5 & 21 days & 60 \\
\hline MK-D & $1: 1: 3$ & & 1.7 & 21 days & 60 \\
\hline MK-E & $1: 1: 3$ & & 1.7 & 21 days & 20 \\
\hline MS & Lime-metakaolin-sand & Sepiolite & & & \\
\hline MS-A & $1.1: 3$ & $10 \%$ & 2.7 & 21 days & 20 \\
\hline MS-B & $1.1: 3$ & $5 \%$ & 1.7 & 21 days & 20 \\
\hline MS-C & $1.1: 3$ & $15 \%$ & 1.7 & 21 days & 20 \\
\hline MS-D & $1.1: 3$ & $10 \%$ & 1.7 & 21 days & 20 \\
\hline PC & Lime-WPC-sand & & & & \\
\hline PC-A & $9: 1: 30$ & & 0.8 & 21 days & 50 \\
\hline PC-B & $2: 1: 9$ & & 0.8 & 21 days & 50 \\
\hline PC-C & $1: 1: 6$ & & 0.8 & 21 days & 50 \\
\hline NHL & Nat. hydr. lime-sand & & & & \\
\hline NHL & $1: 3$ & & 0.8 & 21 days & 50 \\
\hline Aerial L & Lime-sand & & & & \\
\hline $\mathrm{AL}$ & $1: 3$ & & 1.0 & 24 weeks & $20^{\circ} \mathrm{C}$ \\
\hline
\end{tabular}

a Semi-activated metakaolin.

components of MK-lime pastes [11-14]. However, there is still some disagreement about the specific phases formed depending on the mixing proportions, setting and curing conditions, composition or impurities of the raw materials used, as well as on the long term influence factors in their transformations. For instance, usual hydraulic phases produced during pozzolanic reaction between lime and $\mathrm{MK}$ are $\mathrm{CSH}$, and two metastable hexagonal hydrates $\left(\mathrm{C}_{2} \mathrm{ASH}_{8}\right.$ and $\mathrm{C}_{4} \mathrm{AH}_{13}$ ), which can transform into stable cubic hydrogarnets (HGs) $\left[\mathrm{C}_{3} \mathrm{~A}(\mathrm{~S})_{3-x}(\mathrm{H})_{2 x}\right.$, (with $\left.\left.0 \leq x \leq 3\right)\right]$ according to Silva and Glasser [15]. This produces a volume reduction and a porosity increase, which means cohesion loss and less durability expectations. Frías [12-14] stated that both stable and metastable phases can coexist in the absence of lime, even at temperatures up to $60^{\circ} \mathrm{C}$. This had already been shown in the phase diagram proposed by Damidot and Glasser [16] for the $\mathrm{CaO}-\mathrm{Al}_{2} \mathrm{O}_{3}-\mathrm{SiO}_{2}-\mathrm{H}_{2} \mathrm{O}$ system at $25{ }^{\circ} \mathrm{C}$, and most likely to be applicable up to $85^{\circ} \mathrm{C}$. This diagram shows which phases can exist in equilibrium with each other. Klimesch and Ray [17] found that HG stability decreases with the increase of silica content in the bulk composition and it was increased in the presence of Portlandite and lime-rich calcium silicate hydrate.

Few studies have been carried out on blended cement-lime mortars, perhaps because these mixes are not very interesting for cement or concrete technology. Apart from a few cases where lime is used as an addition to modify cement mortars, most recent researches about mixes of lime-cement focus on their influence in the physical structure of the resulting mortar. Some of them study their pore structure and their relation with permeability $[18,19]$ or with their mechanical behaviour [20], which states the advantages of these mortars regarding both the cement-based and lime-based ones. Another study analyses the influence of the type of lime in the viscosity of a lime-cement paste [21], reaching as a result that the determining factor is its morphology rather than its chemical composition.

Finally, sepiolite has been used for cement reinforcement, finding that it improves both flexural and compressive strength because of the network structure induced within the cement matrix [22]. But used as an addition to lime, sepiolite reduces its mechanical strength when $10 \%$ of lime is substituted, attributed to binder reduction and the necessary water increase, due to high clay absorption and adsorption [8].

\section{Materials, testing equipment and experimental techniques}

Materials used for the present research have been products commercially available in the market. Three different binders have been used: a high calcium lime, (classified as CL-90-S according to the European Standard ENV 459-1) from Calcasa (Madrid) as the basic reference binder for all the samples; a natural hydraulic lime, (classified as NHL-Z 3,5 according to the European Standard ENV 459-1) from Lafarge (France) to compare samples with the blended hydraulic lime-based ones; and a white Portland cement (classified as BL 22.5 X according to the Spanish Standard UNE 80305) from Portland Valderrivas (Madrid) used as an addition.

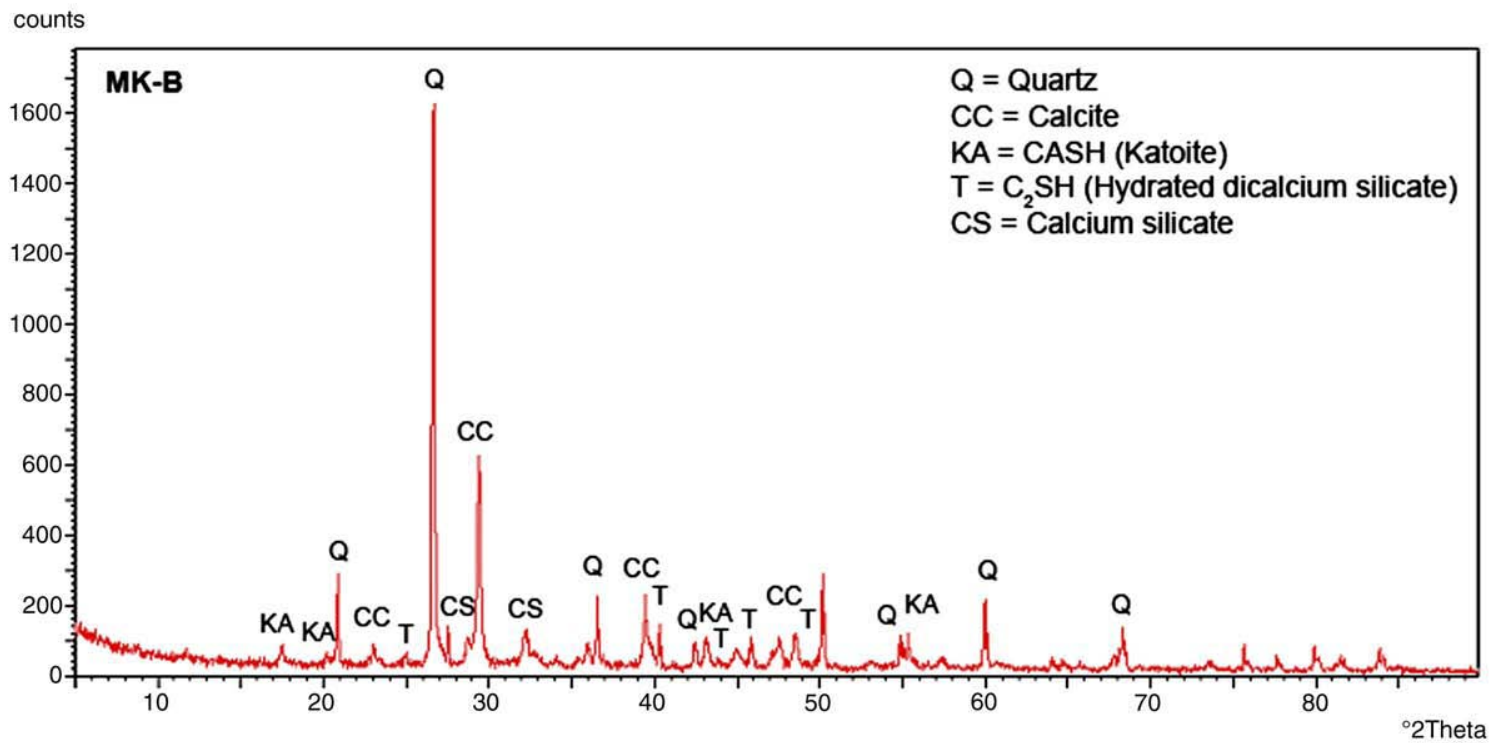

Fig. 1. XRD diagram of the MK-B samples of lime-metakaolin mortar (see Table 2 for details). 


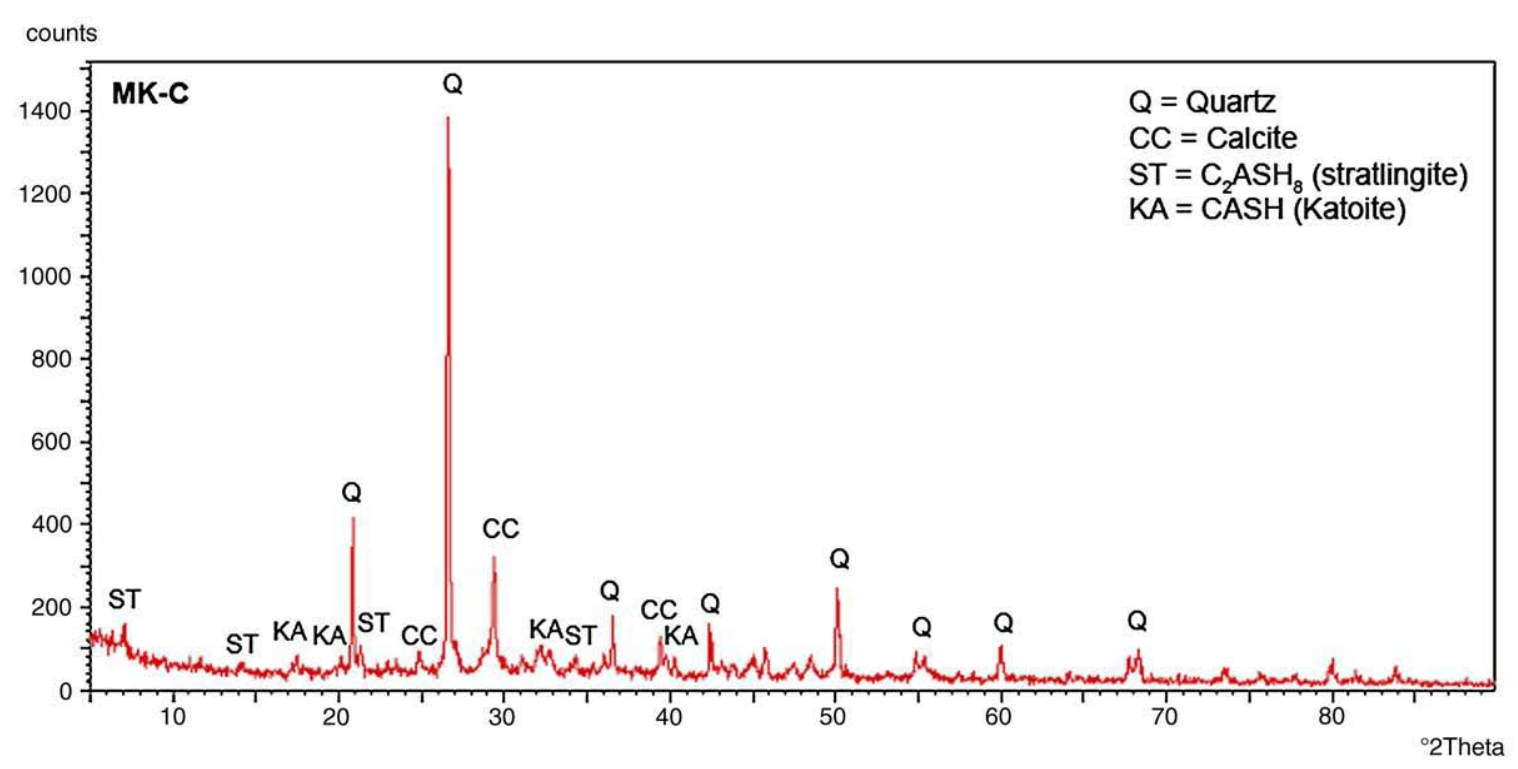

Fig. 2. XRD diagram of the MK-C samples of lime-metakaolin mortar (see Table 2 for details).

As hydraulic modifiers, two other addition products were used, kaolin from Caobar, S. A. (Guadalajara), and a dry micronized sepiolite, Pansil from Tolsa, S. L. (Madrid) (see table 1 for chemical composition). Both were thermally activated into pozzolans through firing in an electric kiln as is later described. Siliceous sand was used as aggregate according to CEN UNE-EN 196-1 standard: 1996. This type was selected from Torroja Institute (C.S.I.C. Madrid, Spain) with particle size distribution between 0 and $4 \mathrm{~mm}$ to minimize its influence on setting, and to assure good particle bonding and strength development.

The testing facilities used for strength and elasticity tests were a hydraulic loading machine equipped with a $50 \mathrm{kN}$ Ibertest-Codein, S. L. load cell, model PBI-5, and LVDT Solartron, mod. AX/2.5/S for strain registering.

For thermal tests two different simultaneous TG-DTA thermal analysers were used: a Stanton-Bedcroft, model STA-781, with platinum-rhodium thermocouples, in $\mathrm{N}_{2}$ flux $(80 \mathrm{ml} / \mathrm{min})$, alumina $\alpha$ as inert reference and a heating rate of $10^{\circ} \mathrm{C} / \mathrm{min}$, and a Seiko, model 320-U with mass spectrometer Thermostar Pfeiffer, mod. GSD 300T3, and Argon as carrier gas.

Scanning electronic microscopy (SEM) was carried out with a Jeol, mod. JSM-6400 with a working tension of $20 \mathrm{kV}$, and an Oxford, model Link Pentafet microanalyzer EDX.

XRD patterns were obtained with a Philips, model X'Pert, with an X-ray source operating at $45 \mathrm{kV}$ and $40 \mathrm{~mA}$, with two slits ( $1^{\circ}$ divergence and anti-scatter $1^{\circ}(0.05 \mathrm{~mm})$ for secondary optic), and with a curved copper monochromator to avoid $\mathrm{K}_{\beta}$ lines.

Pozzolanic activation of kaolinite and sepiolite was accomplished, according to literature [23-28], heating kaolin samples at $700{ }^{\circ} \mathrm{C}$ to obtain metakaolin (MK) and the samples of sepiolite (SP) at $830^{\circ} \mathrm{C}$. Results were checked through TG-DTA at static air atmosphere and XRD. It was verified that $1 \mathrm{~h}$ of heating was the minimum time to complete MK transformation for a $2.500 \mathrm{~cm}^{3}$ tray of material.

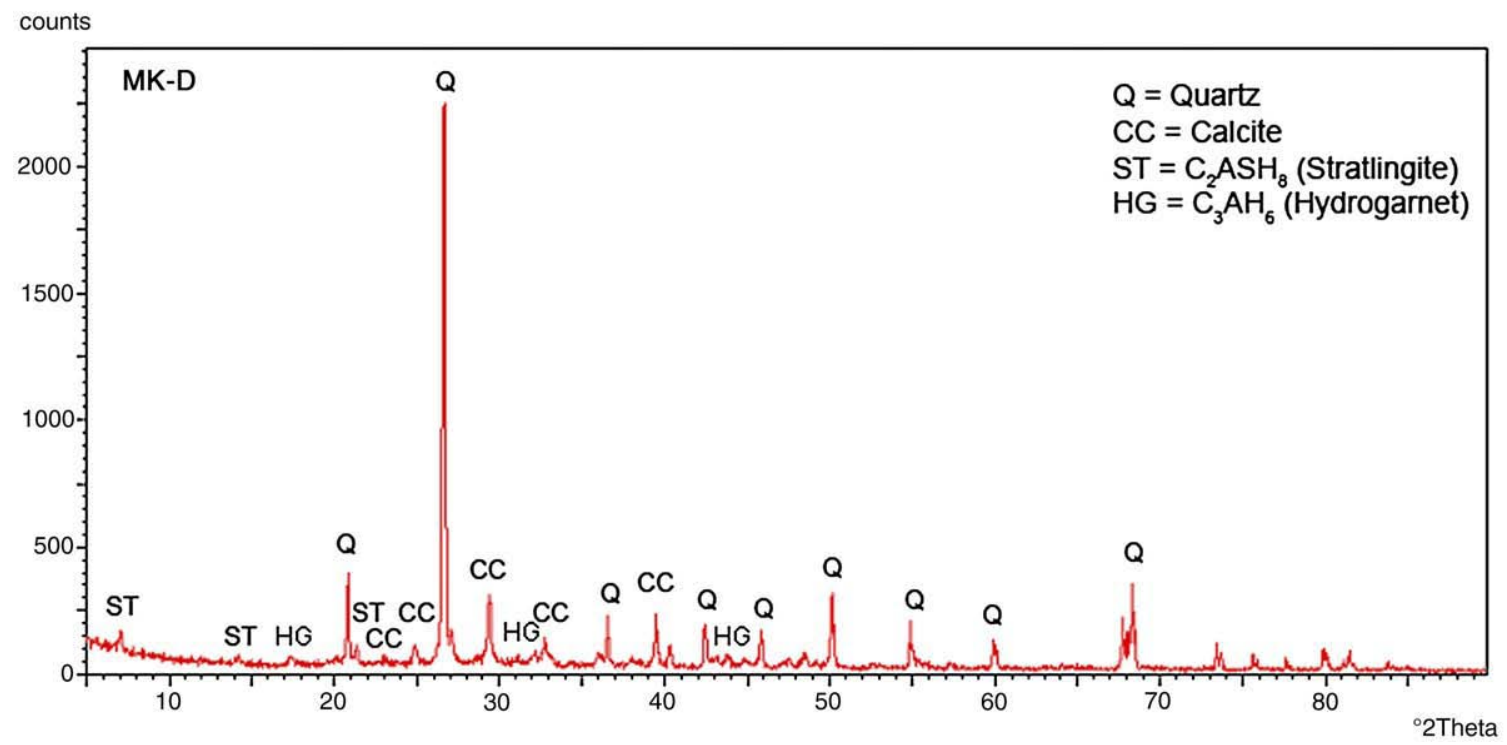

Fig. 3. XRD diagram of the MK-D samples of lime-metakaolin mortar (see Table 2 for details). 
Mortars were mixed in different proportions by weight, using a mechanical orbital mixer and compacted with a vibration table after mould filling.

Samples of $40 \times 40 \times 160 \mathrm{~mm}^{3}$ were performed, and removed from the moulds 2 days later. The air-curing and water-curing process is described next. High temperature underwater curing conditions were chosen in order to accelerate strength and bonding development. This known behaviour in hydraulic binders did not affect other results of this research because mainly, comparisons were made between similar cured samples. After curing, specimens were dried for $24 \mathrm{~h}$ in an oven at $105^{\circ} \mathrm{C}$, and cooled off before testing. Thermal, X-ray and microscopic analysis were carried out after mechanical tests had been performed, reusing the grounded tested specimens.
Different series of lime mortars and blended cement-lime mortars were performed as follows:

AL reference series: aerial lime-sand 1:3, water/binder ratio of 1 , air-cured during six months.

MK series: lime-MK-sand, with different mixing ratios and curing times (see Table 2 for specific details). Semi-activated MK fired only for half an hour was also used for MK-A samples.

MS series: lime-MK-sand, with a partial substitution of 5,10 and $15 \%$ of MK with sepiolite, and cured for 14 days under water at $20^{\circ} \mathrm{C}$.

PC series: lime-white Portland cement-sand, with different mixing ratios and curing times under water at $50{ }^{\circ} \mathrm{C}$ (see Table 2 for specific details).

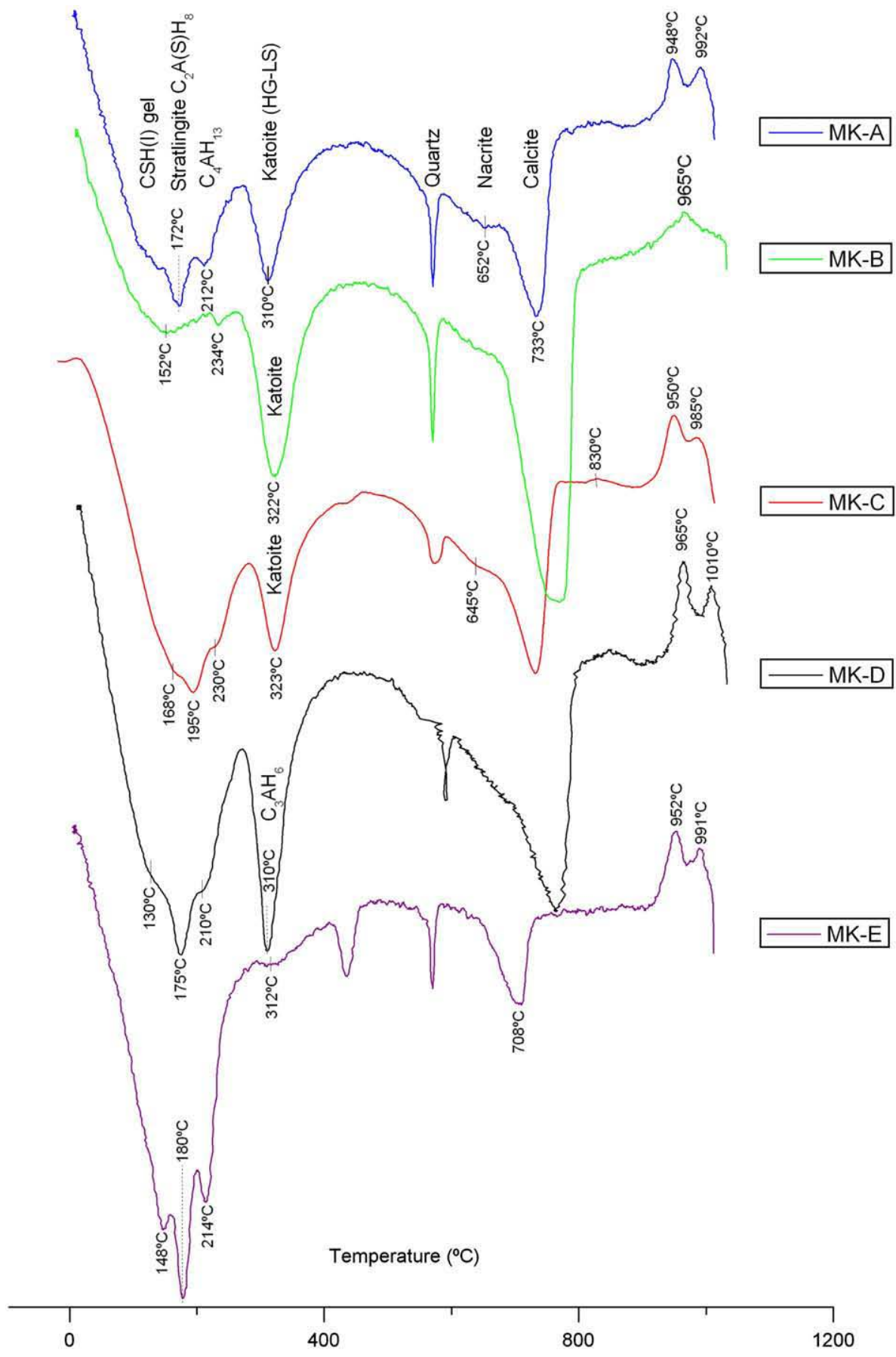

Fig. 4. DTA diagrams of the MK samples of lime mortar with added metakaolin (see Table 2 for details). 
NHL series: natural hydraulic lime-sand, with different mixing ratios and curing times under water at $50{ }^{\circ} \mathrm{C}$ (see Table 2 for specific details).

\section{Results and discussion}

DTA is a thermalanalytic technique that provides data on the specific temperature ranges at which each phase decomposes on heating. As a result, a quantitative assessment of the different phase ratio in every series of samples is achieved.

A first group of calcium silicate and calcium aluminate hydrates dehydrate in the temperature range of 120 to $250{ }^{\circ} \mathrm{C}$, at which $\mathrm{C}-\mathrm{S}-\mathrm{H}$, $\mathrm{C}_{2} \mathrm{ASH}_{8}$ (stratlingite) and $\mathrm{C}_{4} \mathrm{AH}_{13}$ exist. A second endothermic peak in the temperature range $300-360{ }^{\circ} \mathrm{C}$ corresponds to hydrogarnets decomposition. And finally, portlandite dehydrates between 400 and $500{ }^{\circ} \mathrm{C}$ (around $450{ }^{\circ} \mathrm{C}$ in this case). Two other endothermic peaks appeared, the first one corresponds to calcium carbonate decomposition at the temperature range of $600-750{ }^{\circ} \mathrm{C}$ and second one showing quartz inversion at $575^{\circ} \mathrm{C}$ (both in heating and cooling ramps), which comes from mortar siliceous aggregate. There is also another bulging produced by several recrystallization exothermic peaks comprised between $950^{\circ} \mathrm{C}$ and $1000^{\circ} \mathrm{C}$.

Using simultaneously DRX (Figs. 1-3) and differential thermal analysis literature $[17,29,30]$ each peak obtained in DTA graphics was identified. These phases present in the different hydrated samples are indicated in Figs. 4-6.

In MK series (Fig. 4), corresponding to lime mortar samples with metakaolin added, there is a hydraulic stable cubic phase of hydrogarnet ( $\mathrm{HG}$ ), besides metastable ones like $\mathrm{C}_{2} \mathrm{ASH}_{8}$ (stratlingite) and $\mathrm{C}_{4} \mathrm{AH}_{13}$. HGs are a typical product of the hydration of aluminate compounds. HGs have not appeared in other cement-lime blended

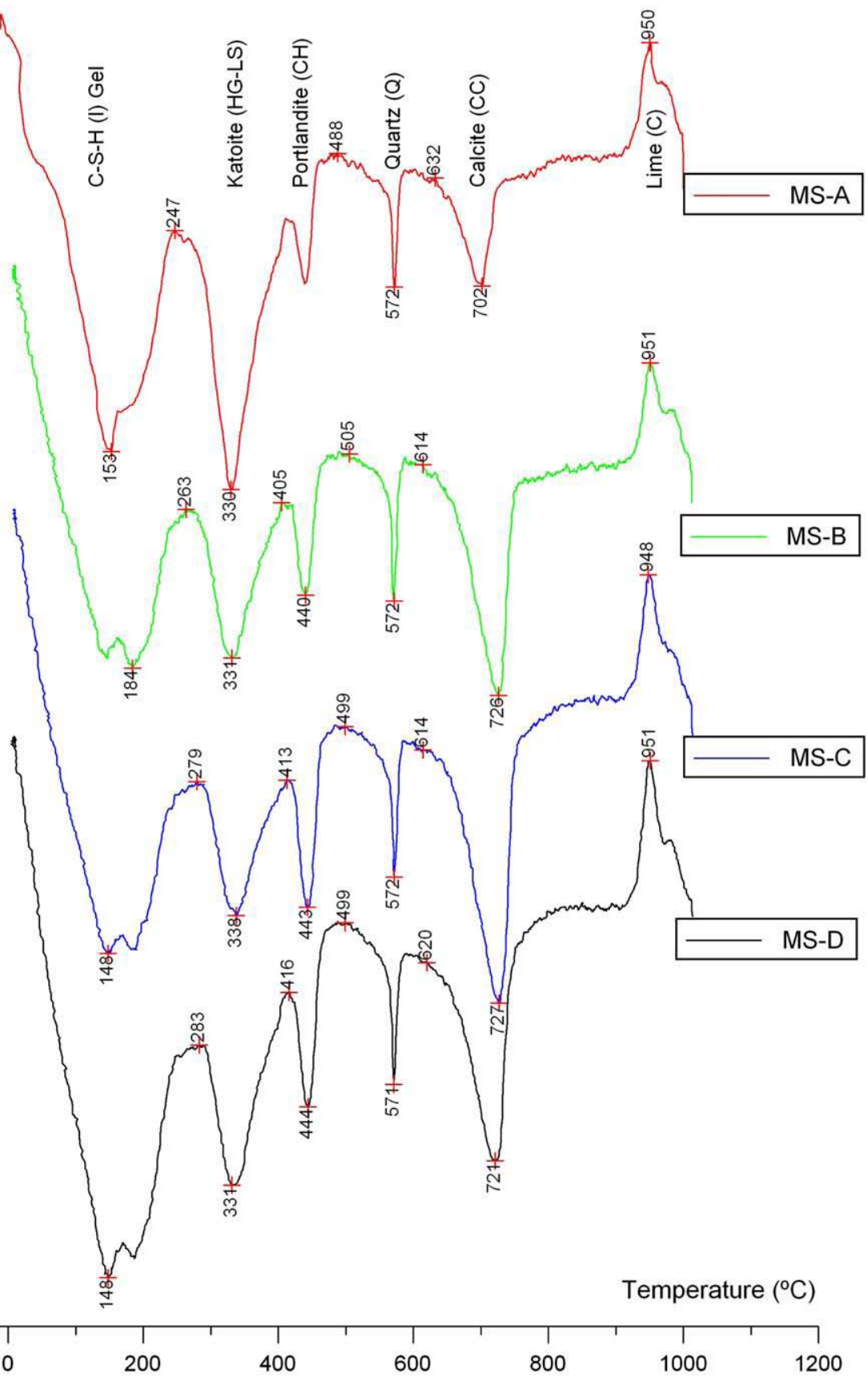

Fig. 5. DTA diagrams of the MS samples of lime mortar with added metakaolin and sepiolite (see Table 2 for details). 


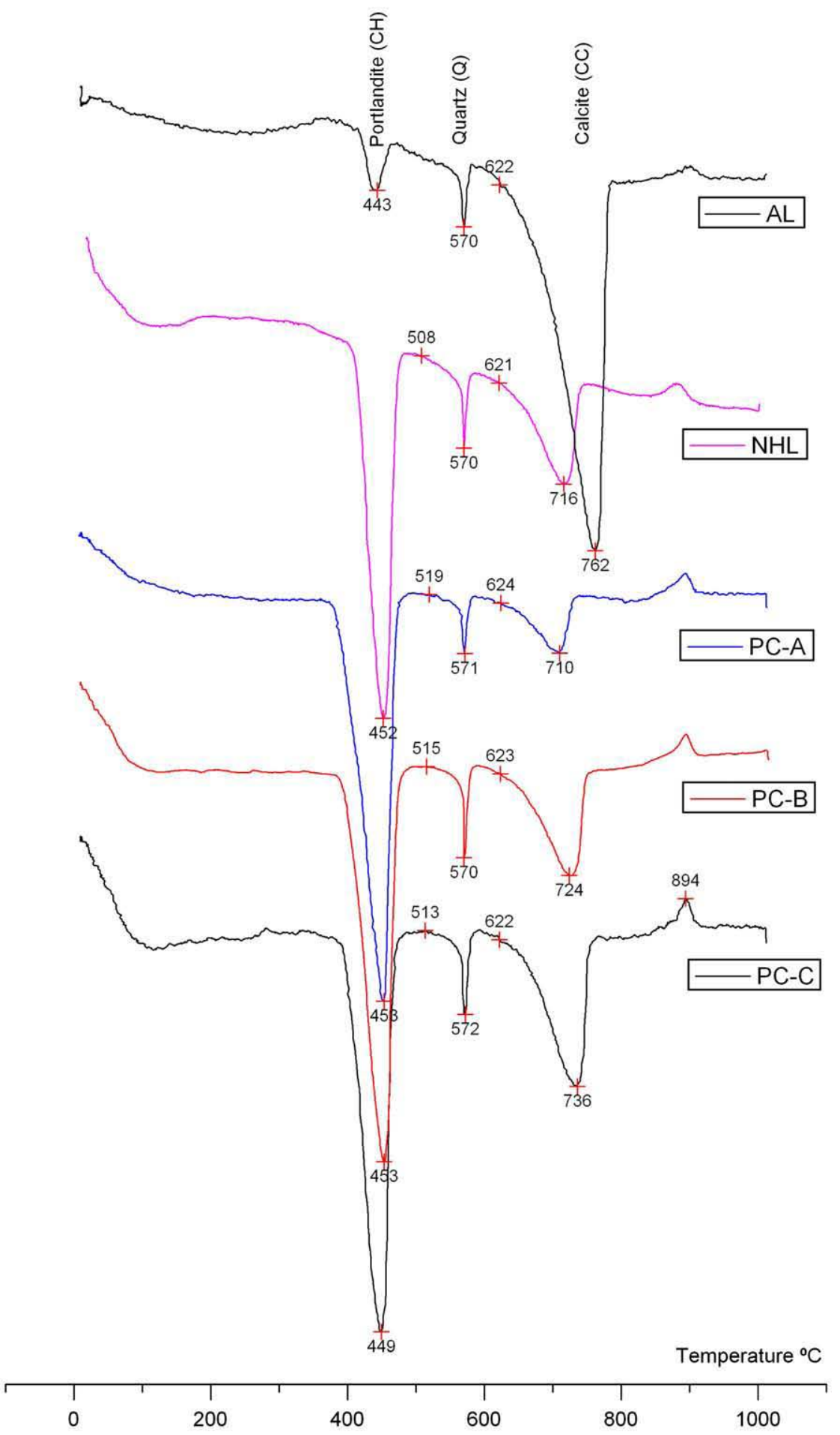

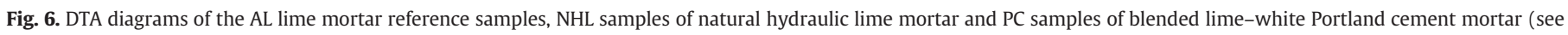
Table 2 for details).

mortars and hydraulic lime mortars tested (Fig. 6), where MK addition is lacking, although they include aluminates too. Therefore, the presence of HGs can be associated with MK addition, according to the $\mathrm{SiO}_{2}$ increase effect suggested by Damidot and Glasser [16]; but with the effect of accelerated nucleation and growth under hot water curing also. Furthermore, reducing half of the MK addition (MK-B series), the HG phase formation does not change significantly. Even though this MK reduction produces a decrease of metastable phases like stratlingite and $\mathrm{C}_{4} \mathrm{AH}_{13}$, it may be due to pozzolan shortage. It is also possible that this reduction is due to a metastable phase evolution. This would explain a slight increase of HG in this last case cured for a longer time. Other two differences observed are: bigger carbonated phases, as expected for longer ages; and the lack of one exothermal peak around $1000{ }^{\circ} \mathrm{C}$, which would correspond to a CSH recrystallized phase. This issue is to be investigated in a next research work.

HGs are classified depending on the silica content. They are formed by the silica substitution of hydroxyl groups in hydrated cement 
pastes. These solid solutions are divided into two groups called lowsilica hydrogarnets (LS HG) and high-silica hydrogarnets (HS HG). Also called katoite $\left[\mathrm{C}_{3} \mathrm{~A}(\mathrm{~S})_{3-x}(\mathrm{H})_{2 x}\right.$, (with $\left.\left.1.5 \leq x \leq 3\right)\right]$, and hibschite $\left[\mathrm{C}_{3} \mathrm{~A}(\mathrm{~S})_{3-x}(\mathrm{H})_{2 x}\right.$, (with $\left.\left.0.2 \leq x \leq 1.5\right)\right]$ respectively, with extreme compounds of $\mathrm{C}_{3} \mathrm{AH}_{6}$ (a hydrogarnet without silica) at one end, and $\mathrm{C}_{3} \mathrm{AS}_{3}$ (grossular, a nonhydrated garnet) on the opposite end.

In MK samples two different HGs were present, katoite (MK-A, MK-B and MK-C series) and $\mathrm{C}_{3} \mathrm{AH}_{6}$ (MK-D and probably MK-E series, detected by DTA but too small to be detected by XRD), that is, a lowsilica HG and an extremely low nonsilica HG. In these cases, silica proportion in the bulk composition could not be the determining factor, since the MK addition was the same in all of them, except for MK-B samples, where this addition was half that of the others. The only difference between these two groups is the mixing water binding ratio, ranging from $\mathrm{w} / \mathrm{b}=1.5$ in the first three cases to $\mathrm{w} / \mathrm{b}=1.7$ in the two last ones (see Table 2 for details).

Considering phase proportions again, Frías claims [12] that HG formation is related to portlandite consumption instead of metastable phase transformation. This would explain the results of MK series. Moreover, that is why MK-E samples - the only MK ones cured in cold

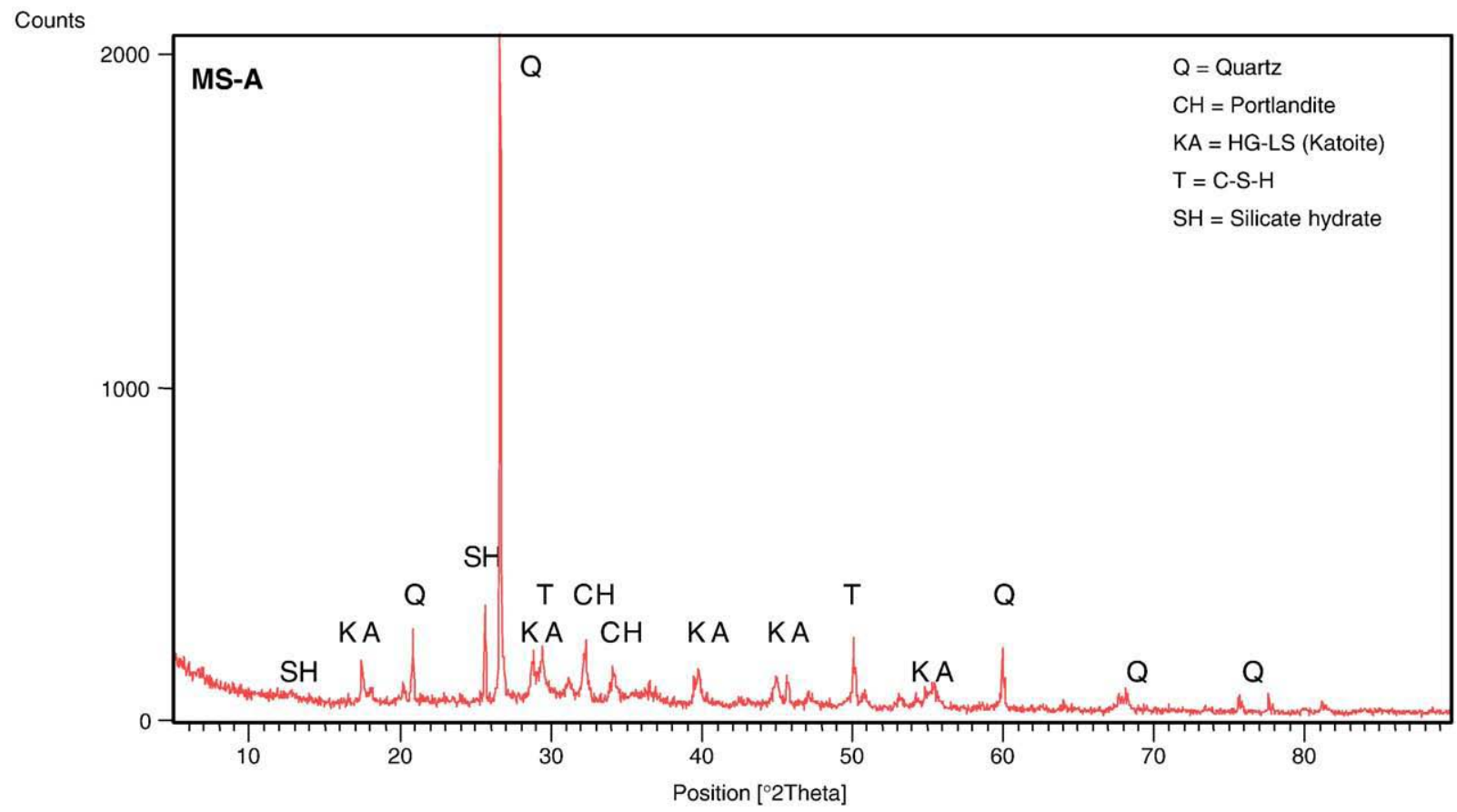

Fig. 7. XRD diagram of the MS-A samples of lime-metakaolin-sepiolite mortar (see Table 2 for details).

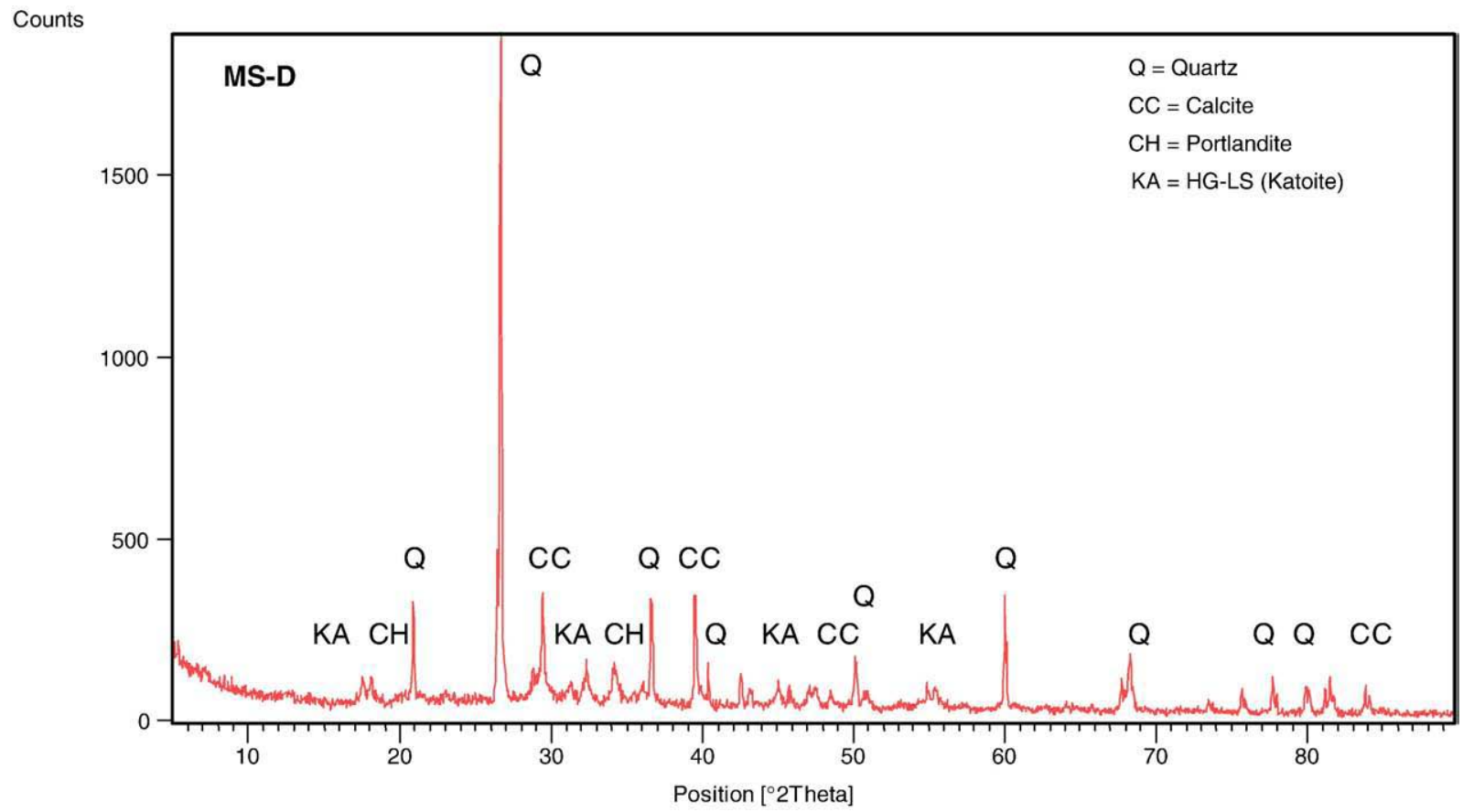

Fig. 8. XRD diagram of the MS-D samples of lime-metakaolin-sepiolite mortar (see Table 2 for details). 
water at $20^{\circ} \mathrm{C}$ - show lower HG formation when portlandite is still present. And it would also justify the inverse relationship between portlandite and HG content in MS series (Fig. 5).

This MS samples are identical to MK ones except for a partial substitution of metakaolin ( $5 \%, 10 \%$ and $15 \%$ ) by sepiolite. In these MS samples, the presence of HG and portlandite is to be observed as in the case of the MK-E samples. Nevertheless, there is neither stratlingite nor $\mathrm{C}_{4} \mathrm{AH}_{13}$ present, as Damidot and Glasser phase diagram stated [16]. Both MS and MK-E specimens share the same water-binder ratio (except for MS-A) and the same cold curing temperature. These similarities cause some portlandite not to be transformed as opposed to what has happened in the other MK samples cured in hot water (Fig. 4).

In MS series, DRX results showed that the HG produced was katoite (Figs. 7 and 8). Higher water-binder ratio should have produced $\mathrm{C}_{3} \mathrm{AH}_{6}$ phase according to MK-E samples, as mentioned earlier. However, the HG obtained is katoite because the presence of sepiolite reduces water availability, due to its great water retention and zeolitic behaviour. Even increasing the w/b ratio to 2.7 in MS-A samples, katoite is formed and in greater amount. High formation of this hydrogarnet, even higher than in the MK samples cured underwater at $60^{\circ} \mathrm{C}$, cannot be caused by portlandite consumption, as it could have happened in this MK series. The presence of HG is not exclusively due to portlandite long term transformation as Frías and Cabrera had stated [12], so, it needs to be a primary product formation, which appears simultaneously to the other hydrated calcium silicate or aluminate compounds. Even at accelerated curing conditions in samples having lower pozzolanic activity - due to less amount of MK or its semi-activation - as in the MK-A and MK-B series, HGs grew faster than the other hydrated phases. This reflects that water/binder rate is an influencing factor on HGs formation. On the other hand, curing water temperature may affect HG amount but it does not determine the hydrogarnet presence, because they were produced regardless of it.

A major difference between MK-E series and MS ones (all cured in cold water) is the presence of another hydrated aluminate, around $210-230{ }^{\circ} \mathrm{C}$, attributed to $\mathrm{C}_{4} \mathrm{AH}_{13}$ phase. This phase does not appear in MS series with added sepiolite, although it is present in different proportions in all samples with metakaolin and no sepiolite, indicating that the later avoids $\mathrm{C}_{4} \mathrm{AH}_{13}$ phase formation.

In addition, MK series show an inverse relation between HGs and $\mathrm{C}_{4} \mathrm{AH}_{13}$ phase. As curing times were similar in all cases, the $\mathrm{C}_{4} \mathrm{AH}_{13}$ phase decrease cannot be due to a long term evolution, even having a HG increase. In our opinion, the remaining factor that explains the presence of $\mathrm{HG}$ and $\mathrm{C}_{4} \mathrm{AH}_{13}$ would be the curing water temperature. But no explanation can be found, at this research level, for the absence of $\mathrm{C}_{4} \mathrm{AH}_{13}$ in MS samples with sepiolite.

Regarding the mechanical behaviour, there is an obvious relationship between the increase of the first group of hydrates, like $\mathrm{CSH}$, stratlingite and $\mathrm{C}_{4} \mathrm{AH}_{13}$ phases and strength. In other words, there is almost no contribution of HGs to it. In MK series, greater strengths correspond to greater stratlingite and $\mathrm{C}_{4} \mathrm{AH}_{13}$ phase content and lower presence of HGs (Fig. 9), which it is even more evident in MS samples (Fig. 10).

As Fig. 9 shows, the greatest strength correspond to MK-E samples cured in cold water with almost no HG formed. This shows an irregular performance, in comparison to the MK-D samples, with the same bulk composition but cured in hot water. Both stratlingite, $\mathrm{C}_{4} \mathrm{AH}_{13}$ and $\mathrm{C}_{3} \mathrm{AH}_{6}$ would imply an unbalanced assemblage according to the phases diagram proposed by Damidot and Glasser [16]. This is what may have caused the strength results. The remaining MK results, as expected, correspond to higher water-binder ratio or higher lime content. The case of MK-A samples with semi-activated metakaolin and relevant strength levels is to be highlighted.

In MS series, mortar strengths were similar, regardless of the amount of MK substituted by sepiolite (at least between $0 \%$ and 15\%

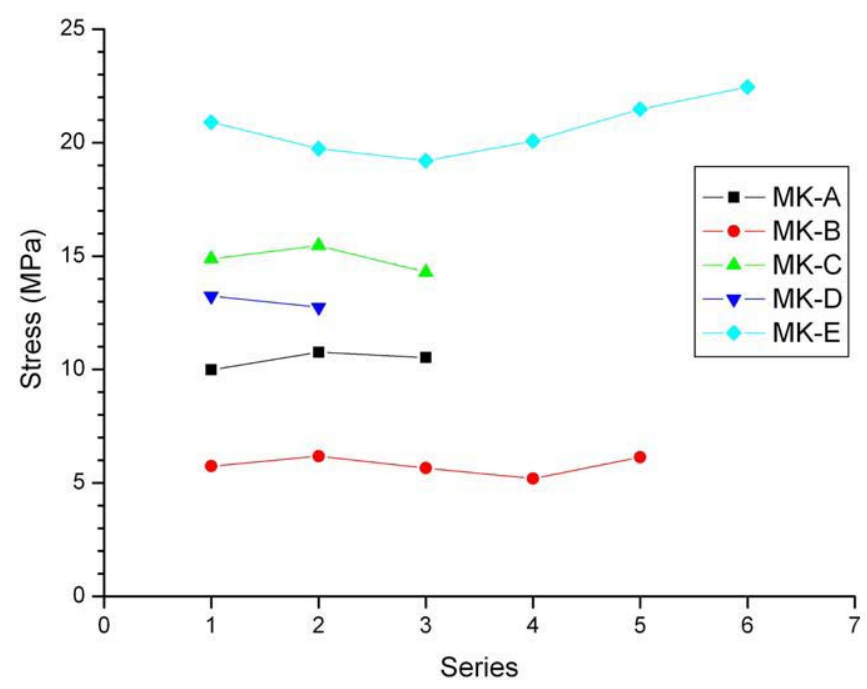

Fig. 9. Strength diagrams of the MK samples of lime mortar with added metakaolin (see Table 2 for details).

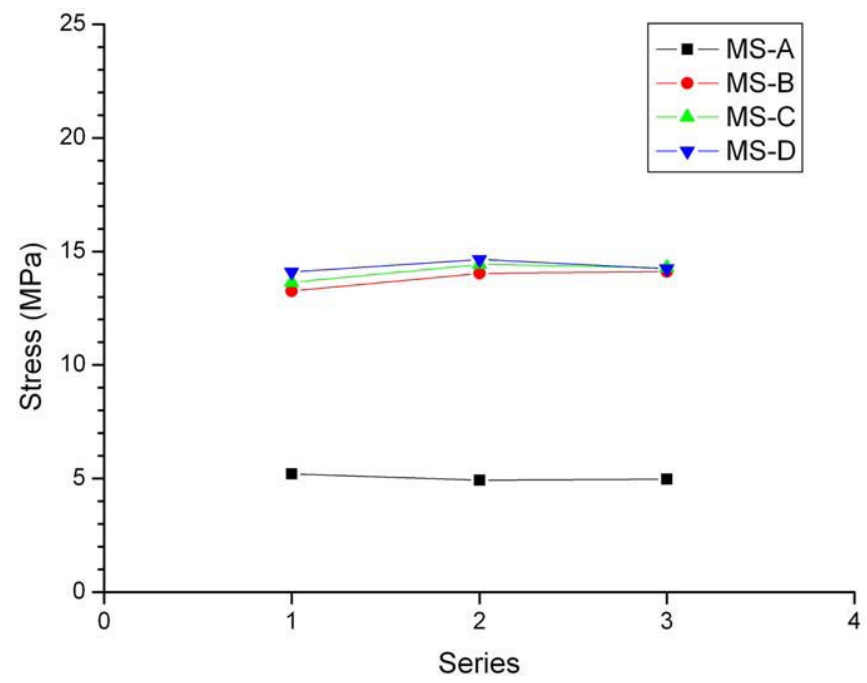

Fig. 10. Strength diagrams of the MS samples of lime mortar with added metakaolin and sepiolite (see Table 2 for details).

by weight), but they were strongly affected by the $\mathrm{w} / \mathrm{b}$ ratio used. A $60 \%$ increase of water addition in MS-A samples reduced their strength almost to $1 / 3$. A reason for it is that the binder quantity does not change in the first case (only metakaolin is reduced), and there is pozzolan enough to react with it. In the second case, water quantity affects the binder setting as expected. This is very important because sepiolite absorption and tixotropic behaviour strongly modifies the rheology of the mortar, and reduced fluency is a main difficulty in grouting. It is also stated that only with low sepiolite addition, similar mortar specimens (MK-E and MS-B, C or D) decrease their strength around $33 \%$, due to a slower hydration process caused by the high water retention of this clay.

On the other hand, in blended lime-Portland cement mortars (Fig. 6), HGs have never appeared, neither at high curing temperatures nor with high Portland cement proportions (even in PC-C series with $50 \%$ lime and 50\% cement). A smooth valley around hydraulic phase decomposition temperatures $\left(100-200{ }^{\circ} \mathrm{C}\right)$ in this last case appears. A similar thermogram is obtained with the NHL samples (Fig. 6) corresponding to a natural hydraulic lime mortar. Hydraulic products formation is too small to be detected by XRD, but mass 
spectrometry of the PC-C samples (Fig. 11) shows its hydraulic nature in $\mathrm{OH}$ and $\mathrm{H}_{2} \mathrm{O}$ curves (masses 17 and 18). It coincides with the NHL samples also, where in SEM micrographs, some of the significant C-S-H rod network, typical of Portland cement hydration, can be seen throughout the specimen analysed (Fig. 12). Surface EDX analysis of the entire photographed area (Fig. 13) suggests the presence of products with mainly high silica-calcium content. This cannot be due to the siliceous aggregate, since the penetration of the SEM electron beam in the sample is quite short affecting only the paste on the surface.

This evolving microstructure observed in SEM, linked to the slope of the curve around this area of $100-200{ }^{\circ} \mathrm{C}$ in DTA diagram (Fig. 6) indicates the mechanical strength development. As expected, higher amount of WPC in the blended lime mortar produced higher strength (Fig. 14), corresponding to deeper valleys in the previous area. At the NLH thermogram (Fig. 6) an even wider and deeper pitch can be seen that explains its greater mechanical resistance and a probable Portland cement addition. Anyway, blended lime-WPC mortars tested in comparison to NHL ones, appear to have similar products formation even at high cement proportions. A moderate strength development

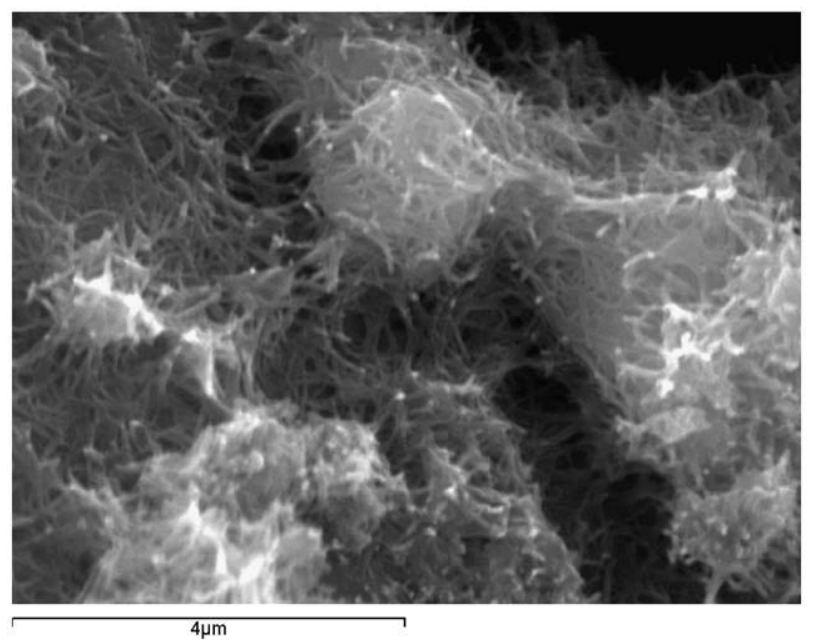

Fig. 12. SEM microphotograph of NHL series sample showing $\mathrm{C}-\mathrm{S}-\mathrm{H}$ rod network throughout the area between silica aggregate and mortar matrix.

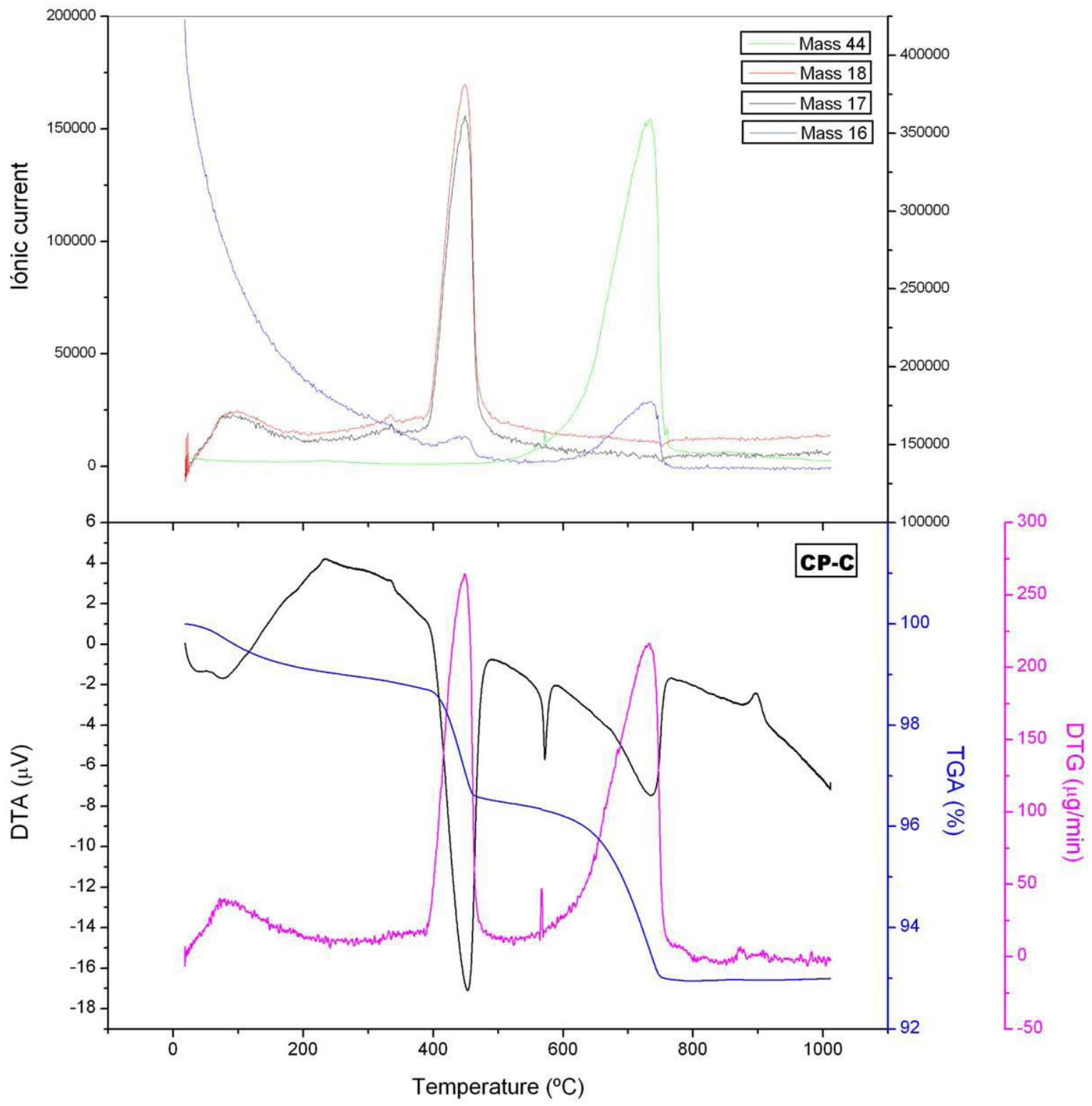

Fig. 11. Simultaneous DTA-TG diagram of the PC-C samples of blended lime-WPC mortar (see Table 2 for details) with mass spectrometry results. 


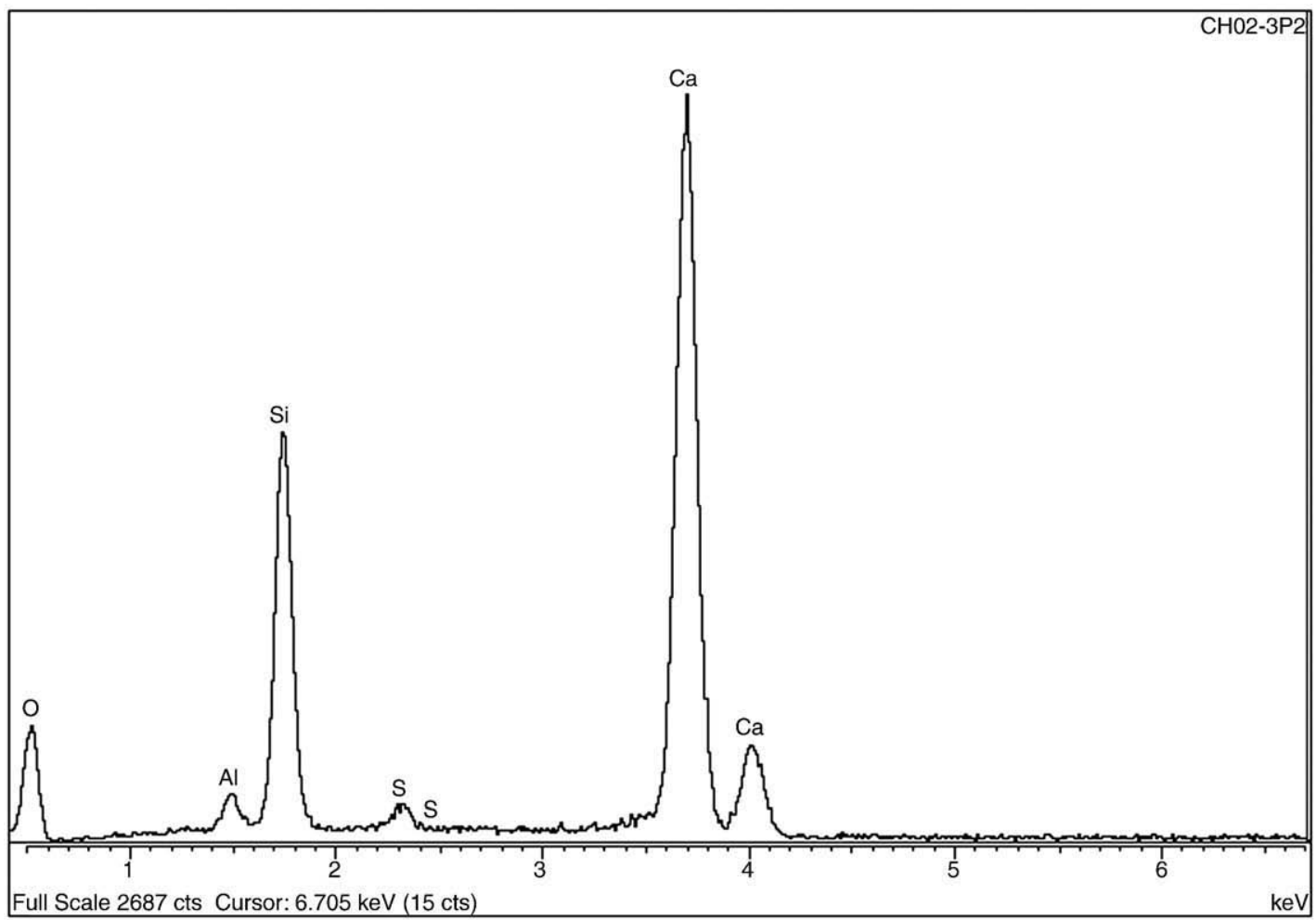

Spectrum processing :
No peaks omitted

Processing option : Oxygen by stoichiometry (Normalised) Number of ions calculation based on 3.00 anions per formula Number of iterations $=2$

Standard :

Al Al203 1-Jun-1999 12:00 AM

Si SiO2 1-Jun-1999 12:00 AM

S FeS2 1-Jun-1999 12:00 AM

Ca Wollastonite 1-Jun-1999 12:00 AM

\begin{tabular}{l|llllllll}
\hline Element & $\begin{array}{l}\text { App } \\
\text { Conc. }\end{array}$ & $\begin{array}{l}\text { Intensity } \\
\text { Corm. }\end{array}$ & Weight $\%$ & $\begin{array}{l}\text { Weight\% } \\
\text { Sigma }\end{array}$ & Atomic\% & Compd\% & Formula & $\begin{array}{l}\text { Number } \\
\text { of ions }\end{array}$ \\
Al K & 0.29 & 0.7788 & 1.34 & 0.12 & 1.20 & 2.53 & Al203 & 0.06 \\
Si K & 3.85 & 0.8692 & 15.79 & 0.23 & 13.63 & 33.78 & SiO2 & 0.71 \\
S K & 0.28 & 0.8554 & 1.16 & 0.12 & 0.88 & 2.90 & SO3 & 0.05 \\
Ca K & 12.29 & 1.0094 & 43.44 & 0.32 & 26.29 & 60.79 & CaO & 1.36 \\
O & & & 38.26 & 0.33 & 58.00 & & & 3.00 \\
Totals & & & 100.00 & & & & Cation sum & 2.17 \\
& & & & & & & CaO \\
\hline
\end{tabular}

Fig. 13. Surface EDX analysis of the area showed in Fig. 12.

of the former is not a significant use limitation, since restoration mortars often need to be weaker than weathered original ones. At least it does not seem to be worse than frequently recommended NHL mortars. Besides, its hydraulicity degree is easier to control adjusting cement ratios.

\section{Conclusions}

Based on the results of this work, the following conclusions can be pointed out:

1. Mixing water proportion is the determining factor for the selection of the hydraulic phase production in the MK-lime blended mortars. A slight increase in $\mathrm{w} / \mathrm{b}$ from 1.5 to 1.7 favours a complete substitution of silica in HG formation.
2. The MK proportion or curing temperature does not affect HGs composition but determines the quantity of them, whereas they are not influenced by portlandite consumption.

3. Sepiolite addition avoids a $\mathrm{C}_{4} \mathrm{AH}_{13}$ phase formation in MK-lime blended mortars, in the conditions studied in this research. This means a strength decrease of about a $66 \%$ in relation to MK-lime mortars with no sepiolite addition cured in water at $20^{\circ} \mathrm{C}$.

4. Biggest strengths in MK-lime blended mortars correspond - apart from $\mathrm{C}-\mathrm{S}-\mathrm{H}$ - to greatest stratlingite and $\mathrm{C}_{4} \mathrm{AH}_{13}$ phase content, resulting in a minimal HGs contribution to mechanical strengths.

5. In blended lime-WPC mortars, even at 1:1 proportion or at high curing temperature $\left(50{ }^{\circ} \mathrm{C}\right)$, HG phases formation are not produced. These mortars have similar composition to the NHL ones, but with much more moderate strength development, which makes them an interesting alternative for restoration purposes. 


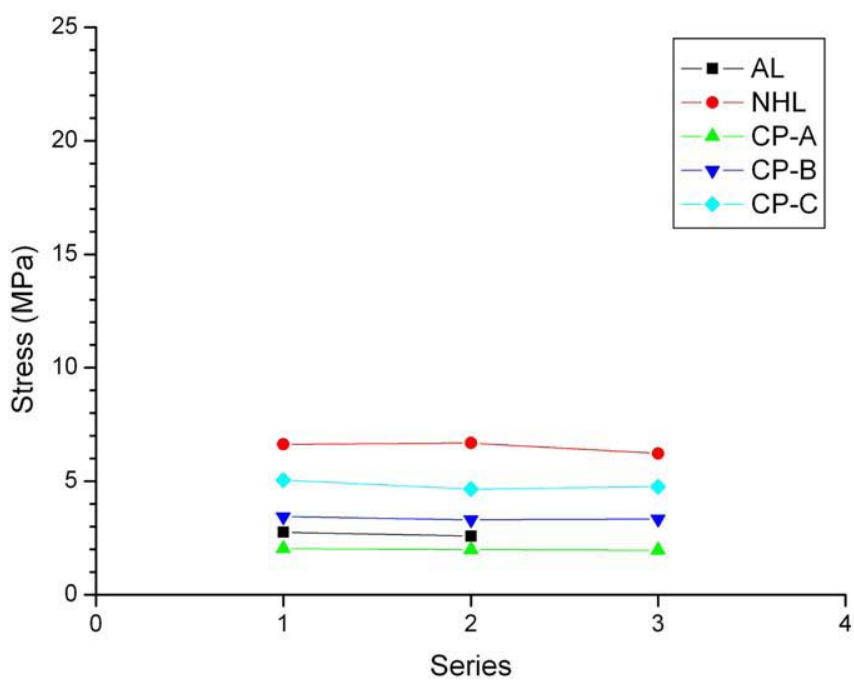

Fig. 14. Strength diagrams of the AL lime mortar reference samples, NHL samples of natural hydraulic lime mortar and PC samples of blended lime-white Portland cement mortar (see Table 2 for details).

\section{Acknowledgements}

The authors would like to thank Rosa $\mathrm{M}^{\mathrm{a}}$ Rojas from Instituto de Ciencia de Materiales de Madrid for her assistance in TG-DTA analysis, Juan Luis Baldonedo and Alfonso Rodríguez from Centro de Microscopía Electrónica "Luis Bru" at Universidad Complutense de Madrid for their help in XRD and SEM analysis, and Isabel Salto-Weis for the language revision.

\section{References}

[1] ASTM E2260 - 03 Standard Guide for Repointing (2003).

[2] R.C. Mack, F.A.I.A., J.P. Speweik, Preservation Briefs 02: Repointing Mortar Joints in Historic Masonry Buildings. (1976, updated Oct. 1998) http://www.nps.gov/hps/ tps/briefs/brief02.htm.

[3] B.M. Feilden, Conservation of historic buildings. $1^{\text {st }}$ ed. 1982, Architectural Press/ Butterworth-Heinemann, Oxford (1994).

[4] ICCROM, Cements, Mortars and Grouts in the Conservation of Historic Buildings, Prepr. of ICCROM symp., 3-6/XI/1981, Rome, 1982.

[5] P. Maravelaki-Kalaitzaki, A. Bakolas, A. Moropoulou, Physico-chemical study of Cretan ancient mortars, Cem. Concr. Res. 33 (2003) 651-661.

[6] G. Baronio, L. Binda, Study of the pozzolanicity of some bricks and clay, Constr. Build. Mater. 11 (1) (1997) 41-46.
[7] B.B. Sabir, S. Wild, J. Bai, Metakaolin and calcined clays as pozzolans for concrete: a review, Cem. Concr. Comp. 23 (2001) 441-454.

[8] S. Martínez-Ramírez, F. Puertas, M.T. Blanco, Carbonation process and properties of a new lime mortar with added sepiolite, Cem. Concr. Res. 25 (1) (1995) 39-50.

[9] M.S. Martínez-Ramírez, F. Puertas, et al., Effect of dry deposition of pollutants on the degradation of lime mortars with sepiolite, Cem. Concr. Res. 28 (1) (1998) $125-133$.

[10] H. Zibara, R.D. Hooton, et al., Influence of the $\mathrm{C} / \mathrm{S}$ and $\mathrm{C} / \mathrm{A}$ ratios of hydration products on the chloride ion binding capacity of lime-SF and lime-MK mixtures, Cem. Concr. Res. 38 (2008) 422-426.

[11] J. Cabrera, M. Frías, Mechanism of hydration of the metakaolin-lime-water system, Cem. Concr. Res. 31 (2001) 177-182.

[12] M. Frías, J. Cabrera, The effect of temperature on the hydration rate and stability of hydration phases of metakaolin-lime-water systems, Cem. Concr. Res. 32 (2002) 133-138.

[13] M. Frías, M.I. Sánchez de Rojas, The effect of high curing temperature on the reaction kinetics in MK/lime and $\mathrm{MK} /$ blended cement matrices at $60{ }^{\circ} \mathrm{C}$, Cem. Concr. Res 33 (2003) 643-649.

[14] M. Frías, Study of hydrated phases present in a MK-lime system cured at $60{ }^{\circ} \mathrm{C}$ and 60 months of reaction, Cem. Concr. Res. 36 (2006) 827-831.

[15] P.S. Silva, F.P. Glasser, Phase relation in the system $\mathrm{CaO}-\mathrm{Al}_{2} \mathrm{O}_{3}-\mathrm{SiO}_{2}-\mathrm{H}_{2} \mathrm{O}$ relevant to metakaolin-calcium hydroxide hydration, Cem. Concr. Res. 23 (1993) 627-639.

[16] D. Damidot, F.P. Glasser, Investigation of the $\mathrm{CaO}-\mathrm{Al}_{2} \mathrm{O}_{3}-\mathrm{SiO}_{2}-\mathrm{H}_{2} \mathrm{O}$ system at $25^{\circ} \mathrm{C}$ by thermodynamic calculations, Cem. Concr. Res. 25 (1) (1995) 22-28.

[17] D.S. Klimesch, A. Ray, DTA-TGA evaluations of the $\mathrm{CaO}-\mathrm{Al}_{2} \mathrm{O}_{3}-\mathrm{SiO}_{2}-\mathrm{H}_{2} \mathrm{O}$ system treated hydrothermally, Thermochim. Acta 334 (1999) 115-122.

[18] M.J. Mosquera, B. Silva, et al., Addition of cement to lime-based mortars: effect on pore structure and vapour transport, Cem. Concr. Res. 36 (2006) 1635-1642.

[19] A. Colantuono, S. dal Vecchio, et al., Cement-lime mortars joining porous stones of masonries able to stop the capillary rise of water, Cem. Concr. Res. 26 (6) (1996) 861-868.

[20] M. Arandigoyen, J.I. Alvárez, Pore structure and mechanical properties of cementlime mortars, Cem. Concr. Res. 37 (2007) 767-775.

[21] Y. Sébaïbi, R.M. Dheilly, M. Quéneudec, A study of the viscosity of lime-cement paste: influence of the physico-chemical characteristics of lime, Constr. Build. Mater. 18 (9) (2004) 653-660.

[22] T. Kavas, E. Sabah, M.S. Çelik, Structural properties of sepiolite-reinforced cement composite, Cem. Concr. Res. 34 (11) (2004) 2135-2139.

[23] M. Murat, Hydration reaction and hardening of calcined clays and related minerals I. Preliminary investigation on metakaolinite, Cem. Concr. Res. 13 (1983) 259-266.

[24] M. Murat, Hydration reaction and hardening of calcined clays and related minerals II. Influence of mineralogical properties of the raw-kaolinite on the reactivity of metakaolinite, Cem. Concr. Res. 13 (1983) 511-518.

[25] G. Kakali, T. Perraki, et al., Thermal treatment of kaolin: the effect of mineralogy on the pozzolanic activity, Appl. Clay Sci. 20 (2001) 73-80.

[26] A. Shvarzman, K. Kovler, et al., The effect of dehydroxylation/ amorphization degree on pozzolanic activity of kaolinite, Cem. Concr. Res. 33 (2003) 405-416.

[27] C. He, B. Osbaeck, E. Makovicky, Pozzolanic reactions of six principal clay minerals: activation reactivity assessments and technological effects, Cem. Concr. Res. 25 (1995) 1691-1702.

[28] C. He, E. Makovicky, B. Osbaeck, Thermal treatment and pozzolanic activity of sepiolite, Appl. Clay Sci. 10 (5) (1996) 337-349.

[29] V.S. Ramachandran, R.F. Feldman, P.J. Sereda, Application of Differential Thermal Analysis in Cement Research, Highway Research Record, vol. 62, Highway Research Board, Washington, D.C, 1964, pp. 40-61.

[30] D.S. Klimesch, A. Ray, DTA-TGA of unstirred autoclaved metakaolin-lime-quartz slurries. The formation of hydrogarnet, Thermochim. Acta 316 (1998) 149-154. 